[Revised for Studies in Higher Education 30 June 2017, accepted for publication]

\title{
Limitations of human capital theory
}

Simon Marginson

UCL Institute of Education, University College London, UK; and Melbourne Centre for the Study of Higher Education, University of Melbourne, Australia

\section{Contact details}

Simon Marginson (corresponding author)

UCL Institute of Education

University College London

20 Bedford Way

London WC1H 0AL

United Kingdom

Office phone: +44 (0) 207626341

Mobile: +44 (0) 7876323949

Email: s.marginson@ucl.ac.uk

\section{Word count}

Text and notes 7635 words, references 1751 words, title page and abstract 291 words.

\section{Bio}

Simon Marginson is Professor of International Higher Education at the UCL Institute of Education, University College London, UK, and Director of the ESRC/HEFCE Centre for Global Higher Education. He is Joint Editor-in-Chief of Higher Education. 


\title{
Limitations of human capital theory
}

\begin{abstract}
Human capital theory assumes that education determines the marginal productivity of labour and this determines earnings. Since the 1960s it has dominated the economics, and policy and public understanding, of relations between education and work. It has become widely assumed that intellectual formation constitutes a mode of economic capital, higher education is preparation for work, and primarily education (not social background) determines graduate outcomes. However, human capital theory fails the test of realism, due to weaknesses of method: use of a single theoretical lens and closed system modelling, inappropriate application of mathematical tools, and multivariate analysis of interdependent variables. Human capital theory imposes a single linear pathway on the complex passage between heterogeneous education and work. It cannot explain how education augments productivity, or why salaries have become more unequal, or the role of status. These limitations are discussed with reference to research on social stratification, work, earnings and education.
\end{abstract}

\section{Keywords}

human capital theory; educational policy; critical realism; philosophy of education; sociology of education 


\section{Limitations of human capital theory ${ }^{1}$}

\section{Human capital theory}

Since its modern beginnings at the turn of the 1960s (Mincer 1958; Schultz 1959, 1960, 1961) and fuller development by Gary Becker (1964), human capital theory has constituted a fecund research programme in the economics of education, associated with many thousands of empirical studies. In the foundational narrative of human capital theory, education drives the marginal productivity of labour and marginal productivity drives earnings. Correspondingly, the value of investment in education is defined by the lifetime earnings of educated labour. Education, work, productivity and earnings are seen in linear continuum. When educated students acquire the embodied productivity (the portable human capital) used by employers, graduate earnings follow. In the pure and original form of the idea, higher education more or less automatically triggers private enrichment, career success and national economic growth. The claim about the contribution to economic growth made by aggregated investment in education as human capital, first asserted baldly by E.F. Denison (1962) and developed with more econometric sophistication in endogenous growth theory's account of education and knowledge in technologically-driven development (Romer 1990), is now a common policy assumption (Psacharopoulos 1994; Keeley 2007). In some countries, data on private rates of return to graduates are used to regulate the private/public split in education financing, between fee payments and government subsidies (Chapman, Higgins and Stigltiz 2014), though there is debate about the respective roles of public and private investment.

The dominance of human capital theory in the economics of education is matched by its authority in the public and policy domains. Nevertheless, as discussed immediately below, there is a gap between the world imagined in the theory and the real economic and social world in which it is applied, and this gap may be growing. This article will argue that human capital theory's failure to meet the test of realism derives not from lack of sophisticationsince its foundation there have been various innovations designed to increase its empirical purchase and utility - but from its meta-method. The limitations in meta-method, which are discussed below, have led in turn to a flawed and narrow understanding of education/workand the first mover authority of human capital theory has stymied alternative conceptions.

\section{The theory and its policy contexts}

Founding modern human capital theory was the product of a particular historical moment that favoured its genesis and spread. It evolved amid the building of mass higher education in the United States (US) (Kerr 2001). The theory provided a rationale for the governmentsponsored expansion of higher education, while also promising to efficiently regulate the pace and cost of expansion on the basis of the measured economic returns to graduates. The main ideas were propagated internationally by the United Nations Educational, Social and Cultural Organisation (UNESCO 1968) and later the Organisation for Economic Cooperation and Development (OECD). They became general to economic policy at the same time as another policy discourse, social rather than economic, that of equality of opportunity through education. In the conjuncture, the two policy ideas were necessary to each other (Marginson 2016a). The policy goal of equality of opportunity promised to optimise the economics of education by ensuring that all available productive talent would become educated. Human capital theory provided an economic justification for investment in expanding educational opportunity. In Capital in the twenty-first century (2014) Thomas Piketty shows that between the 1950s and the 1970s conditions in the United States were unusually favourable for the 
reception of these ideas (Marginson 2016a, 3-4). The potential for upward social mobility via higher education was high. Professional jobs were growing rapidly; income from inherited capital was at historically low levels; and to an extent not seen before or since, income from work was the main source of wealth (Piketty 2014, 241). Amid excess demand for educated labour all graduates could obtain good jobs. This appeared to confirm human capital theory in practice and also underpinned contemporary optimism about the potential of higher education to create a fairer and more efficient society, in which educated merit and hard work would determine success, rather than prior family position. Piketty notes that Becker's (1964) mathematization of human capital theory is permeated by the belief that all forms of capital other than human capital (that is, financial, social and cultural capital) have lost their determining importance (Piketty 2014, 385). The 1960s expansion of opportunity and social mobility enabled human capital economists to imagine that the theory was not just necessary in explaining the relationship between higher education and work, it was sufficient.

Half a century later the context is different from that in which Becker published Human Capital. In the 55 countries in which the higher education system includes 50 per cent or more of the youth cohort (Marginson 2016b), in variant and often fluctuating economies, not all graduates enter professional jobs; while income inequality has dramatically increased in the United States (Saez 2013; Piketty 2014, 265), inheritance is more potent (p. 393) and income from capital now outweighs income from labour as a source of wealth (p. 402). The power of family income, social and cultural capital in determining access to both elite higher education and elite professional employment is attested repeatedly in research (e.g. Soares 2007; Rivera 2015; Social Mobility Commission 2016). American social mobility is at a lower ebb than in the 1960s/1970s (Corak 2012; Stiglitz 2013). Regardless, human capital theory continues to shape understandings of relations between higher education and work. One reason is that although equality of opportunity has faltered in societies becoming more unequal, the idea of merit as learned and portable ability retains legitimating power. The notion of human capital, floating free of other forms of capital, implies that those with social advantages succeed not because of their birth and connections, but because of their abilities and powers of application (Hennessy 2014). In a 'hypermeritocratic' parody of the original human capital idea (Piketty 2014, 264-265), the exceptional salaries of American super-managers are legitimated by their prior selection into leading universities (Rivera 2015) and within performance pay regimes by alleged super-productivity in the workplace (Hanley 2011). In this curious backhand way, the core propositions at the heart of human capital theory have 'meritified' self-reproducing privilege, though the normative commitment of economists is often to equality of opportunity.

Many human capital economists have grappled with these problems. Since 1960s the human capital research programme (Blaug, 1976) has taken on greater complexity and the foundational narrative has been considerably supplemented. Becker's later work (e.g. Becker and Murphy 2003) seeks to account for the influence of the social setting on behaviours and choices, in the process extending his 1964 conception of productivity-generating skills and knowledge beyond the education system. Other scholars draw attention to the influence of non-educational factors in earnings. For example, Gerhard Glomm and B. Ravikumar (1992) combine choice-based investment in human capital with the capacity of parents to pass on endowments to their children, which they define as another component of human capital. This provides one possible reconciliation of human capital theory with unequal economic and social outcomes, suggesting that education may generate absolute economic gains through productivity advance while leaving relative benefits unchanged. Liam Delaney, Colm Harmon and Cathy Redmond (2011) investigate parental education as causal in relation to graduate earnings expectations. Jack Britton, Lorraine Dearden, Neil Shephard and Anna Vignoles (2016) study UK graduates with ten years in the labour market, investigating the effects of variations in socioeconomic background, gender, institution attended and field of study. They 
note high dispersion in graduate outcomes (pp. 53-54), and find that 'graduates' family background - specifically whether they come from a lower or higher income household continues to influence graduate's earnings long after graduation' (p. 55). Graduates from higher income households earn at least 10 per cent more at the median than graduates from low income households after factoring out other student characteristics, institution attended and field of study (p. 55). High income origins protect graduates against low earnings and increase their prospects of very high earnings (p. 56). In considering why these data modify expectations created by human capital theory, the authors suggest 'students from wealthier families ... might have access to financial, social and cultural capital'; though they also pose a possible alternative, that students from wealthier families may have greater ability (p. 56).

A feature of human capital economics is that despite the complexities and qualifications introduced by theorists, and notwithstanding marked changes and variations in real-world contexts, the core 1960s propositions of the theory remain intact, at least as a partial truth. Crucially, they still function as a form of default explanation. The other factors, which are often seen by economists as social rather than economic, seem to be pasted on; framed as potential modifiers rather than the basis of an alternative explanation of higher education, work, incomes, income distribution and social outcomes. The human capital economist asks 'why doesn't human capital theory work as it should, and what are the additional elements and modifications needed to make it work as it should?' rather than 'what is a new and better explanation of the relationship between education and work?' Moreover, the economists' qualifications often drop away when human capital calculations are used instrumentally in policy; and the complexification of the theory scarcely impacts the larger public discussion about education and work, in which it is the original and default explanation-rather than the qualifications, complexities and contextual issues - that continues to have shaping effects.

This is because human capital theory has become influential in policy and public thinking not simply as an applied research programme and a set of econometric techniques deployed one way or another, but in the form of a widely-understood metaphor for relations between work and education, that is grounded in the foundational narrative of a linear continuum between education, work, productivity and earnings. It could be argued that this metaphor has become so widespread as to comprise part of the modern 'social imaginary' (Taylor 2007). The popularisation of human-capital-as-metaphor helps explain the 'pervasive belief in the power of degrees to both allocate individuals in the labour market and to serve as job requirements throughout the occupational structure' (Baker 2011, 62). That intellectual formation constitutes a mode of economic capital (Hodgson 2014); that in the first instance higher education can be primarily understood as preparation for work and career; and that education itself, not family income or cultural attributes or social networks, is the starting point for an explanation of career outcomes and earnings: all these notions have (arguably, unduly) elevated education as a social and economic arbiter. For example, in the United Kingdom and Australia, higher education institutions (HEIs) and their disciplines are held to account by government and public on the basis of graduate earnings and/or employment rates in the early years of work, regardless of other elements that affect employment and earnings. Correspondingly, the idea of education as self-investment in one's own capital positions graduates (or their portable human capital) as responsible for individual success/failure and weakens the obligation of government to steer a more equal income distribution.

By no means all economists would endorse those conclusions. Few would agree with the simplified version of the relations between higher education and work current in much policy rhetoric and public debate. Most professors of economics would firmly reject notions that the value of education can be reduced to its measured effects in earnings or jobs. However, such positions are consistent with the intellectual strategy of human capital theory, which is to protect the original ideas by rendering them more complex and nuanced rather than call them 
into question. The founding paradigm has not been declared obsolete - and like most social scientists, human capital economists are not known for talking down their core idea. In this manner, human capital theory (buttressed by human-capital-as-metaphor) tends to block from view alternative ideas, theories and measures about relations between education and work.

\section{Critiques of human capital theory}

Since its inception human capital theory has been subject to repeated and often devastating critiques. Few scholars from outside mainstream economics with a close research knowledge of education have endorsed human capital theory. Many scholars in the political economy of education and labour have challenged the core narrative, from Samuel Bowles and Herbert Gintis (1976) to Joel Spring (2015). On the economics/sociology border, screening theory sees higher education not as a site of self-investment in cognitive formation that delivers economic returns, but a system for signalling a competitive position that delivers economic returns - an alternative narrative to human capital theory using much the same evidence (e.g. the early study by Berg 1971). Sociologists including Martin Trow (1973), Randall Collins (1979), Ulrich Teichler (2009) and David Baker (2011) provide very different accounts of work and education. In his work on social reproduction in education Pierre Bourdieu (1984, 1988) highlights positional competition and status, which human capital theory cannot encompass, and introduces family cultural capital and social capital networks as central to the explanation, rather than dispensable add-ons. The OECD (2014a) treats social background effects on vocational outcomes, and human capital effects, as intermeshed, without giving priority to one over the other. A large literature explains socially differentiated educational outcomes more as a function of prior inequalities and institutional stratification in education, than individual choices about self-investment in education, pointing to ways in which social inequalities affect aspirations (e.g. Hoxby and Avery 2013) and are reproductive (Boliver 2011, 2013). In The Global Auction (2012) Philip Brown, Hugh Lauder and David Ashton describe declining private returns and dispersion of graduate outcomes amid unequal and exploitative societies, again a different world to that suggested by human capital theory.

However, most critical scholars are at cross-purposes with those they criticise. After all, any theory can be criticised from the standpoint of a different theory; and any discipline can be interrogated from the perspective of another in several ways. But sociological critiques have limited potential to persuade economists or change the minds of economic policy makers for whom economics is the master social science. Rather than posing an alternate theory or discipline as the basis of critique it is more fruitful to go the roots of human capital theory-to interrogate the default narrative in relation to its own purpose, which is to provide a universal explanation of relations between education and work. In this article the basis of critique is historicisation, which tests a theory against the empirical terrain it purports to explain. The emergent weakness of human capital theory is lack of realism. Milton Friedman (1953) argued that economic theory does not need to be realistic to make viable predictions and secure normative effects. Yet for many economists, and more policy makers, a key idea that lacks realism does have a problem. Lack of realism undermines the scope of government to understand and to act.

The present article argues that human capital theory lacks realism in at least four areas. First, human capital theory uses a closed analytical system and independent variables but neither external effects nor co-dependence can be eliminated from the problems it addresses. Second, a linear theory is applied to material that is non-homogeneous in space and time. Third, human capital theory unifies two heterogeneous domains, education and work, as if they are a single domain. Fourth, it eliminates other possible explanations of education/work relations, of which there are many. It is further argued that these weaknesses at the base of 
human capital theory, derive from the underlying meta-method of its social science (Dow 1990), which blocks the possibility of realistic explanations. The problems of meta-method, not unique to human capital theory, are: (1) the theory's claim to a universal theorisation based on a single lens, and its closed system modelling of social relations; and (2) the misapplication of mathematical tools, and in particular, the use of multivariate analysis of social relations in contexts in which the variables are irretrievably interdependent. The article begins with discussion of these problems of meta-method and then moves to the four points above.

The discussion of meta-method draws on critical realism (e.g. Bhaskar 2008, Sayer 2000) and heterodox economics, realist and historicised bodies of thought that work across multiple disciplines and theorisations and use multiple methods. The limitations in human capital theory's understanding of relations between education and work are discussed with reference to selected research on social stratification, work, earnings and higher education.

\section{Problems of meta-method}

\section{Universal lens and closed system}

Human capital theory operates as a single and universal lens. The use of the single exclusive lens rests on the dualistic proposition that there is only one possible truth about social phenomena, and that particular truth has absolute authority (Dow 1990, 2012). In this kind of social science, the researcher applies a fixed theoretical framework and linked methodology to a succession of empirical observations in different sites. The theory is seen as universally applicable to all sites. Obversely, the only phenomena that can be recognised in observation are those nominated in the template of the theory. It is as if one objective of each act of research is to affirm the theoretical components by identifying and codifying them. The weight of successive papers seems to 'prove' the master theory but it is a test that tends to guarantee its own result. The possibility that the master theory is more applicable to some social sites than others is not considered. However, the succession of similar narratives has diminishing returns, in that they are increasingly less likely to create new knowledge.

Two lacunae follow from the use of a single exclusive lens. First, as suggested, observation is stymied in sites where the single lens does not readily apply to the material. Second, other possible explanations, arising from the use of the many other lenses, are obscured. Researchers using a single lens might acknowledge limitations of their study but rarely question the capacity of the master theory to address any possible problem.

For universal explanations to work they need closed systems with limiting premises. However, critical realism argues that social structures are always partly open, to other structures and agents, and historical contingency (Sayer 2000). While a temporary partial closure is necessary in any research and analysis, the problem arises when analytical closure is placed beyond interrogation and has the force of a fixed and permanent law, as with human capital theory. This creates conditions for fallacies. Tony Lawson critiques neoclassical economics on the grounds that it imagines the economy as a closed system operating by deductive logic. 'Deductivism' is 'the thesis that closed systems are essential to social scientific explanation (whether the event regularities, correlations, uniformities, laws, etc., are either a prior constructions or a posterior observations)' (Lawson 2012, 3-4).

By deductivism I mean a type of explanation in which regularities of the form 'whenever event $x$ than event $y$ (or stochastic near equivalents) are a necessary condition. Such regularities are held to persist, and are often treated, in effect, as laws, allowing the deductive generation of consequences, or predictions, when accompanied with the specification of initial conditions. Systems in which such 
regularities occur are said to be closed ... If mathematical methods of the sort economists mostly fall back on are to be employed, closures are required (or presupposed). (Lawson 2003, 5, emphasis in original).

If mathematical sets in economics are universally relevant, strict 'event regularities' must be ubiquitous in the real world. However, when deductivism is used in real life contexts, 'social event regularities of the requisite kind are hard to come by' (Lawson 2003, 13). The alternative is to imagine the economy/education as a partly open system without strict 'event regularities', to acknowledge the partial character of the truth about that system obtained through any one lens, and to open up 'the possibility of a range of approaches' (Dow 2012, 82 ). Theories 'can vary according to changed times and circumstances' (Carabelli and Cedrini 2014, 44). This is also true of the policy applications of theory. Hence, human capital theory is closer to realism under full employment than high unemployment, and more explanatory of investment in financial management education than investment in a music or drama programme with negative rates of return. If no single discipline, theory or methodology has universal reach, by the same token no one explanation excludes, cancels out or invalidates all other explanations. This means that in each research site and problem it is necessary to identify the appropriate theoretical lens, or combine and match the appropriate lenses.

\section{Problems of multivariate modelling}

The high standing of mathematical modelling in much of social science reflects a societywide belief that mathematics is fundamental to science; a conviction (or ideology) that derives not just from the elegant simplification permitted by mathematics, but also from the success of mathematical precision in many domains (Lawson 2012, 16). However, the subject matter of the 'social disciplines' is often inappropriate for mathematical treatment (Carabelli and Cedrini 2014, 31), especially when complex, holistic, synthetic accounts are required. 'The fundamental problem of modern economics is that methods are repeatedly applied in conditions for which they are not appropriate' (Lawson 2012, 1) — mathematical methods are often applied to phenomena they cannot adequately comprehend and problems they are not competent to solve. Mathematical methods have potential in research on education and work, as auxiliary tools in studying relations and comparisons. They can be used to map proportions and changes in bounded sub-systems. But in themselves these methods do not explain, they illustrate. Sayer $(2000,22)$ states: 'Statistical explanations are not explanations in terms of mechanisms at all, merely quantitative descriptions of formal (not substantial) associations'.

One heterodox line of thought in economics rejects the main path taken by methods of mathematisation and statistical modelling in human capital theory and parallel domains, particularly multi-variate analyses that impose arbitrary definitions on indeterminate social variables in complex sites in which many variables are at play. Multivariate statistical analyses use probabilistic methods to distinguish nominal degrees of causality for each one of a set of variables. However, Alfred Marshall argued that when the subject-matter becomes more complex, rather than devising ways of reducing that complexity, the economist should diminish the use of abstract reasoning and mathematics (Marshall 1898, 39). Marshall argued that the problem with much of the use of mathematics in economics is that the econometrician 'takes no technical responsibility for the material, and is often unaware how inadequate the material is to bear the strains of his [sic] powerful machinery' (Marshall 1920/1961, 781). Similarly, John Maynard Keynes noted that mathematical reasoning was formally rigorous yet hostage to the quality of the initial assumptions (Keynes 1936/1973, 297-298).

In reflecting on the limits of statistical inference, Keynes noted that statistical analysis depends on the universal validity of assumptions, and is valid only when the variables used 
are wholly independent of each other (Keynes 1921/1973, 276-277; Carabelli and Cedrini 2014, 28-29; Lawson 2012, 1-2) — a test many multivariate analyses fail to meet. As Keynes remarked, "we are faced at every turn with the problem of organic unity, of discreteness, of discontinuity - the whole is not equal to the sum of the parts, comparison of quantity fails us, small changes produce large effects, the assumptions of a uniform and homogeneous continuum are not satisfied' (Keynes 1933/1972, 262; Carabelli and Cedrini 2014, 36-37).

The 'atomic hypothesis', which justifies inductive reasoning and mathematical calculus, cannot be applied to organic complex systems ... Keynes is critical of the attempt to blindly apply mathematics and statistics, with their assumptions of homogeneity, atomism and independence, to an economic material that is essentially vague and indeterminate, not homogeneous, not divisible in homogeneous independent parts, not finite, and is characterised by organic interdependence (Carabelli and Cedrini 2014, 29-30).

In the same vein, Pierre Bourdieu and Jean-Claude Passeron remark on the interdependent and organic character of the factors affecting social inequality:

It is the system of factors, acting as a system, which exerts the indivisible action of a structural causality on behaviour and attitudes ... so that it would be absurd to try to isolate the influence of any one factor, or, a fortiori, to credit it with a uniform, univocal influence at the different moments of the process or in the different structures of factors (Bourdieu and Passeron 1990/1977, 87).

A multi-variate analysis of relations between higher education and work would require that all relevant variables are independent of each other, each separately interacts with the other variables, and all interactions are governed by a common law. Such conditions hold only in closed systems governed by a single universal logic. They do not apply in the real world of education and work, where many variables under consideration are impossible to conclusively separate from each other, for example family income, cultural capital, 'ability'. Worse, in many (if not most) human capital studies, the statistical correlation or coincidence between two variables is held to constitute not a suggestive association between them, but a demonstration (or a strong suggestion) that they are causally related. It is remarkable how often statistically-based research papers about higher education and earnings conclude with a statement equating correlation with causality, with weak or no qualification, and with little regard for the limits imposed by the contextual conditions in which the data were generated.

By no means all multi-variate analyses are careless of these difficulties. Multicollinearity and endogeneity have generated a large literature. However, efforts to compensate for their problems from within the method cannot be conclusive; and if the limitations of the research are fully acknowledged its precision and its generic claims are fundamentally undermined. This suggests that the solution often lies in stepping outside the multivariate framework.

\section{Problems of human capital theory}

These problems are now considered specifically in relation to human capital theory.

\section{Bounded statistical analysis and organic realities}

The OECD sees human capital theory as necessary but not sufficient, noting that 'a host of education-related and context-related factors' other than learning itself 'affect the returns to 
education' (OECD 2014a, 151). Richard Arum and Josipa Roksa are more sceptical, arguing that 'colleges have little control over wage outcomes' (Arum and Roksa 2014, 125). As noted, there is a long literature on factors that affect earnings, additional to higher education per se. Graduate earnings vary by the differential status and resources of HEIs ('college quality' in the US literature); family income (Wolniak et al. 2008, 131); family life not mediated by education (Triventi 2013, 45) including support for child development such as whether children are read to at a young age (Corak 2012, 6); measured 'ability'; type of secondary school; and social and family networks at entry to higher education, entry to work and later careers (Bingley, Corak and Westergard-Nielsen 2011; Hallsten 2014, 20; Arum and Roksa 2014, 14; Borgen 2015.). Earnings are affected by varying customs and hierarchies in professions and workplaces; by the wage determination system and the industrial balance of power (Piketty 2014, 305); and the configurations and fluctuations of economies. Given these factors - which are all constantly changing - it is delusional to seek to measure or compare the quantity, quality or productivity of education programmes, institutions or systems, on the basis of the private rates of return to, or the rate of employment of, those graduates.

Statistical methods design to eliminate the effects of factors other than higher education flounder given the number of variables, their interdependency, and the impossibility of isolating each causal factor from all the others. This in turn leads to problems of selection effects. The economist struggles to find causality in the face of multicollinearity problems but the comparisons are contaminated by hidden factors. It must be said the problem of selection effects is a non problem grounded in the assumption that elements are atomistically separable. Nevertheless, in research premised on the assumption of atomism the problem must be solved. Attempts to account for selection effects generate diverse results. Reviewing research on graduate earnings in China, Hongbin Li and colleagues note that while some researchers identify returns to college selectivity after selection effects are accounted for, others find these returns disappear. Much of the variation in findings is due to arbitrary assumptions about selection effects, not variations in the real world (Li, Meng, Shi and Wu 2012, 78-79).

\section{Non-homogenous and non-linear material}

Human capital theory also fails to deal effectively with real world sites in which patterns are non-linear and non-homogeneous. Nicolai Borgen remarks in relation to studies of graduate outcomes that while averages create order from diversity, they do so 'by masking important heterogeneity across the wage distribution' (Borgen 2015, 43). He also identifies non-linear economic returns associated with higher education. Family background effects seem greatest at top end of the wage distribution. 'The returns to college quality are five times larger at the 90th quantile compared to the 10th quantile' (p. 42). Gregory Wolniak and colleagues find that after graduation, education is associated with a growing impact on earnings, in non-linear fashion (Wolniak et al. 2008, 131). Paul Bingley, Miles Corak and Niels Westergård-Nielsen researched the 'intergenerational transmission of employers' between fathers and sons. In both Canada and Denmark, 30-40 per cent of young adults at some time work for a firm that has employed their fathers. In both countries, the transmission of employers was positively associated with paternal earnings, 'rising distinctly and sharply at the very top of the father's earnings distribution' (Bingley et al. 2011, 3, 7 and 12.). Again at the top end on incomes, Iftikhar Hussain and colleagues find the apparent income effects of selective institutions inflate, and returns associated with degrees are increasing (Hussain, McNally and Telhaj 2009, 12). Thomas Lemieux (2006) finds that in the US, over thirty years, 'within-group inequality grew substantially among college- educated workers, but changed little for most other groups' (p. 195). 'The median, the tenth and the ninetieth percentiles are remarkably stable for up to 12 years of education'. However, 'above 12 years of education... the return to 
education at the ninetieth percentile increases much more than the return to education at the tenth percentile, leading to a large increase in the 90-10 gap' (p. 196). Lemieux concludes that 'changes in wage inequality are increasingly concentrated in the very top end of the wage distribution...' [and] 'postsecondary education plays a crucial role in explaining this phenomenon' (p. 199). The empirical data are consistent with Bingley et al. (2011) and Borgen (2015), but Lemieux's interpretation is questionable. Is the concentration at the top end of incomes an effect of higher education, as Lemieux suggests, or due to something else?

These empirical patterns are consistent with Piketty (2014) and Emmanuel Saez (2013) on income inequality in the US. In 2012 the top 1 per cent of income recipients received 22.5 per cent of all income, second highest level since 1928 (Saez 2013, 7-9). Non-linear returns at the top end of the income distribution cannot be explained by human capital theory without introducing factors from outside the theory, eroding it claim as a universal lens. For if returns to labour are simply driven by the chain of human capital and marginal productivity, then income inequality must also derive from unequal skills and productivity. Piketty comments wryly that while 'US educational institutions... surely need to be improved and made more accessible', they 'probably do not deserve such extravagant blame' (Piketty 2014, 330):

This very sharp discontinuity at the top income levels is a problem for the theory of marginal productivity: when we look at the changes in the skill levels of different groups in the income distribution, it is hard to see any discontinuity between 'the 9 percent' and 'the 1 percent', regardless of what criteria we use: years of education, selectivity of educational institution, or professional experience (Piketty 2014, 314).

The reality, however, is that higher education is largely decoupled from the surge in top incomes (Piketty 2014, 315 and 330). The recent broad consensus among scholars studying work-based incomes in the US is that the blow-out in managerial salaries is more a price effect than an education effect (e.g. Autor, Katz and Kearney 2008, 317-318; Mouw and Kallenberg 2010; Hanley 2011; Bentele 2013; OECD 2014b), one grounded in tax cuts for high income earners and work-related practices such as salary deregulation, de-unionisation and performance-pay. Human capital theory cannot explain sharp variations in graduate incomes over time, nor differences in patterns of income distribution, and top-end earnings, in countries with similar higher education. 'A major problem' facing 'marginal productivity theory' is that 'the explosion of very high salaries occurred in some developed countries but not others. This suggests that institutional differences between countries rather than general and a priori universal causes such as technological change played a central role' (Piketty 2014, 315, also 304, 308, 321). Nevertheless, the non-linear earnings pattern is suggestive, implying that higher education affects American occupational outcomes less among highincome earners than among middle level earners. While this again undermines the universal claim of human capital theory it suggests a fruitful opening for further research.

\section{Heterogeneity of higher education and work}

The human capital equations unify higher education and work at the cost of suppressing much that is distinctive about each. Arguably, work and higher education are different kinds of social site, each with its distinctive history, requirements, daily practices, subject-positions, rhythms and drivers. This does not mean work and higher education are unconnected. Graduation is associated with higher employability and earnings (OECD 2014a, 102-170), whether due to superior attributes of graduates or their positioning in the labour markets. Some higher education is in continuum with work (e.g. selective programmes that train 
professionals such as doctors), and many higher education programmes have occupational contents. Students and graduates, HEIs, professions and employers often make strenuous efforts to connect education and work. However, the linear transition imagined in the human capital narrative does not describe higher education/work relations. The transition is often fraught. The education/work alignment is partial and unclear. Relations between the two domains are multiple, context-bound, fragmented, uneven and must be continually worked on.

For many graduates job allocation lacks precision, especially in US higher education with a high proportion of generic degrees (Roksa 2005, 225). Josipa Roksa and Tania Level state:

Many educational credentials have no obvious matches in the labour market. This includes the majority of high school graduates in general and academic tracks and a large portion of college graduates majoring in liberal arts and sciences. Consequently, finding a job in one's field of study is not only an individual dilemma, it is a process that reflects the relationship (or lack thereof) between the educational system and the labour market (Roksa and Levey 2010, 391).

Barbara Schneider and David Stevenson $(1999,79-85)$ find that only 44 per cent of students had 'aligned' educational ambitions, meaning they planned to complete the amount of education required by their intended occupations (Arum and Roksa 2011, 34). Many students keep their vocational options open. Often they enrol for more reasons than vocational planning, studying subjects they are good at, or they enjoy, while hoping the future will work out. Though this strategy embodies uncertainty, because all graduates have a positional advantage in the labour market vis a vis non graduates such confidence is not wholly misplaced. John Robst $(2007,398)$ notes 'the eventual match between degree field and occupation is uncertain when selecting a major'. He finds that 55 per cent of respondents report a close relation between their work and field of study, 25 per cent state they are 'somewhat related', and 20 per cent that they are not related (p. 402), though Robst has difficulty defining the work-relatedness of general degrees.

Even among specifically trained graduates, many enter occupations that are outside their fields of training, often not always with income penalties (Melguizo and Wolniak 2012, 383; Robst 2007, 403-404; van der Werfhorst 2002, 301). This lack of fit between formal training and work reflects the messy way that labour markets operate. Many professional jobs are generic. They can be filled by graduates from any field, and level of education, and possibly institution attended, are more significant than field of study. Many graduates take jobs that provide the best pay and career prospects at the time of selection. At this career point some will depart from their qualifications and a proportion never return. Some specialised positions are filled by persons trained in specialist fields other than that of the position. For their part, employers select the 'best' person from the available pool. Specific training and qualifications is only two of the factors in play. Studies of graduate selection indicate that the attributes of potential employees that influence selection also include institution attended, extra-curricular activities as students, subjective perceptions of 'fit' between graduate and workplace, and personal ties (e.g. Bingley et al. 2011; Rivera 2015; Tholen et al. 2013; Borgen 2015).

There is more vocational specificity in education and predictable pathways to work in countries such as Germany than in the US. In Germany this is achieved not by market coordination in education and work as Becker imagined, but by 'tight linkages between occupational groups, education and training practices, and certification boards'. German practice appears to conform 'nicely to human capital models' but 'these completely fail to capture the importance of the elaborate institutional framework that enables the German certification regime to operate as they predict' (Hansen 2011,32). Nor does human capital 
theory explain how education enhances productivity (p. 43) which remains a black box. One constraint is its methodological individualism (Lukes 1973). It is impossible to accurately attribute enhanced value to individuals working in a combined workplace, as are most employees (Piketty 2014, 330-331).

\section{Other explanations of education and work}

Human capital theory understands only some students/graduates, those who consider the lifetime earnings attached to different choices and weigh them against the costs of study. Many students/graduate fail at being a choice-making self-investing homo economicus. Jens Thomsen and colleagues report that at enrolment some students ignore forgone earnings during study (Thomsen et al. 2013, 471). Others know graduate earnings only in their chosen occupation, not related fields (Robst 2007, 399). Borgen $(2015,34)$ states that many students do not 'self-select into colleges based on expected gain'. Students have many interests in addition to credentials, future earnings and careers, including network building (Armstrong and Hamilton 2013); the accumulation of knowledge, generic skills and cultural capital; intellectual formation as an end in itself; cultural activities; and social or political activism. They mix their goals, practices and modes of reflexivity. However, if one other effect is admitted then human capital theory can no longer function as a closed system.

Because it is a closed system human capital theory has never adequately addressed its cousin, screening theory. There is evidence for the presence of the signalling function (just as there is evidence some students estimate lifetime earnings in different jobs), though screening no more constitutes a universal explanation than does human capital theory. For example, Arum and Roksa $(2014,80-81)$ note that business graduates have strong early wage returns, despite relatively low measured cognitive formation in that field. 'Some majors serve as better signals of employability than others, regardless of whether those degrees are underpinned by actual field-specific knowledge and skills'. OECD data on earnings suggest that in some countries the returns to qualifications exceed the returns to measured skills, in other countries the ratio is reversed (OECD 2014a, 109). Both human capital and signalling effects are at play (and without excluding other effects). Yet often social scientists feel obliged to choose between them (e.g. Wolniak at al. 2008, 124-125; Hu and Vargas 2015, 3; Bake, 2011, 8).

Human capital theory also fails to encompass occupational and social status in education and work, which is not fully captured by the earnings function. Arum and Roksa $(2014,57)$ emphasise: 'Rewards to occupations are related not just to income but also to occupational status and prestige. In social settings, individuals are typically asked about what they do, not how much money they earn'. Many studies identify status goals and effects, and variations in the respective roles of earnings and status outcomes, by gender, by field of study and 'college quality', between countries and over time (e.g. Arum and Roksa 2014, 80-81; Triventi 2013, 55-57; Zhao 2012; Thomsen et al. 2013, 471; Hu and Vargas 2015; Hennessy 2014, 47). Investigating outcomes for 13-year out graduates, Roksa finds that for those with generic degrees working in the public and non-profit sectors, a managerial role is often more attractive than higher earnings. 'Graduates of female-dominated fields are disproportionately employed in public and non-profit organizations which offer lower monetary rewards but facilitate access to professional and managerial positions' (Roksa 2005, 207). The passage of time affects income and status in contrasting ways in different fields of study. 'Occupationally specific degrees are beneficial at the point of entry into the labour market but have the lowest growth in occupational status over time' (Roksa and Levey 2010, 389), though they do better in earnings (p. 399). Separately associated with both level of education and political standing, status opens the way to jobs and income. Moris Triventi (2013) in four European countries, and $\mathrm{Hu}$ and Vargas (2015) in China, find that 'college quality' is associated with higher 
occupational status. Hu and Vargas (2015) note that status is a signal of prestige to employers and correlates with the likelihood of assuming a managerial position (p. 19).

\section{Conclusions}

Human capital theory presents its core propositions about education, learning, productivity and earnings as a necessary and sufficient truth about higher education and work, albeit (in some studies and to varying degree) joining these core propositions at the periphery to caveats and moderating factors. The theory's claim about its universal application, in conjunction with the intellectual and policy dominance it has long exercised, has disrupted the possibility of a social science of education and work at a higher level of real world complexity.

Higher education and work are different and separated social sites though there are important overlaps in practice. This is not a relationship of identity, regularity or a linear continuum. Nor is it a dialectic, in which two contrasting parts form a unified system with a shared logic. Education and work are heterogeneous in relation to each other. Their relations are never wholly resolved or resolvable in practice; and if a final resolution is attempted in theory then something can be lost from view (for example, the generic or liberal component of intellectual formation in higher education, which has no specific vocational aspect, slips from empirical sight, or appears negative). Relations between higher education and work are also context bound. They vary by country, field of study, type of institution, financing of education, occupation, industry, employment site and over time. For example, both David Goodman (2014) and Wei Zhao (2012) note that status drivers are especially important in China, arguably playing a larger role in comparison with income drivers than in the US. The task of a realist study of education/work is to combine sensitivity to context with an account of larger patterns, including aspects of social relations not directly observable (Sayer 2000). These patterns are both internal and external. Like all semi-bounded systems, the dyad of higher education and work is connected to other systems or 'fields' (Bourdieu 1993; Fligstein and McAdam 2015), including income determination and wealth creation, labour markets, state and politics, taxation, public spending and programmes, global flows.

Given that education/work relations entail complex and multiple phenomena-and no theorisation can contain all phenomena, while retaining a bounded coherence - it is axiomatic that more than one description of education/work relations can provide useful insights. Gerber and Cheung $(2008,301)$ canvass four possible reasons for the higher earnings of graduates of elite institutions: elite HEIs impart more valuable human capital, elite graduates signal their status to employers, students in elite HEIs garner more valuable social capital, graduates from elite HEIs have enjoyed advantages such as family affluence or ability that generate more favourable outcomes. However, in this paper they do not consider the possibility that all four factors are in play, with the mix varying over time and between countries and between fields of study. In orthodox sociology, as in orthodox economics, theoretical multiplicity is mostly a bridge too far. The drive for universal explanation, that elusive talisman of social science, overrides real-world complexity. Hansen (2011) rightly argues that all major theories of education/work relations, such as human capital, signalling and 'credentialist' certification' are 'to some degree wanting' (p. 31). The obverse is also true. Differing research-based explanations of education and work contribute to knowledge. Some are more explanatory than others. Confronting the complexity of education/work, the task of research is to determine which explanation(s) are primary, not to impose an exclusive straightjacket on the material.

It is not the purpose here to outline an alternate theorisation to human capital economics. However, an alternate approach would be grounded in a meta-method that would use a semiopen analytical system or model, admit multiple theories rather than one exclusive theory, and draw on both quantitative and qualitative research and combine their insights. Statistical 
reasoning would have a modest role. In slicing into parts of the empirical terrain, statistical studies can be suggestive. For example, in research on top-end graduate incomes, the findings become interesting where the linear patterns break down. The limits of statistical analysis show not when it is used for specific inquiry but where it purports to provide a holistic picture, when it is substituted for an historicised synthesis, and multi-variate modelling and calculation are used as a substitute for more difficult processes of complex judgment. The use of multi-variate analysis should be limited to instances when the variables are independent.

\section{Notes}

\footnotetext{
${ }^{1}$ This is an extended version of the keynote address to the annual conference of the Society for Research into Higher Education, Newport, Wales, UK, 9 December 2015. Thank you to Helen Perkins.
} 


\section{References}

Armstrong, E., and L. Hamilton. 2013. Paying for the Party: How College Maintains Inequality. Cambridge, MA: Harvard University Press.

Arum, R., and J. Roksa. 2014. Aspiring Adults Adrift: Tentative Transitions of College Graduates. Chicago, IL: University of Chicago Press.

Autor, D., L. Katz, and M. Kearney. 2008. "Trends in U.S. Wage Inequality: Revising the Revisionists." The Review of Economics and Statistics, 90 (2): 300-323.

Baker, D. 2011. "Forward and Backward, Horizontal and Vertical: Transformation of Occupational Credentialing in the Schooled Society." Research in Social Stratification and Mobility 29: 5-29.

Becker, G. 1964. Human Capital: A Theoretical and Empirical Analysis with Special Reference to Education. Chicago, IL: University of Chicago Press.

Becker, G. and Murphy, K. 2003. Social Economics: Market Behaviour in a Social Environment. Cambridge, MA: Harvard University Press.

Bentele, K. 2013. "Distinct Paths to Higher Inequality? A Qualitative Comparative Analysis of Rising Earnings Inequality among U.S. States, 1980-2010.” Research in Social Stratification and Mobility, 34: 30-57.

Berg, I. 1971. Education and Jobs: The Great Training Robbery. New York: Praeger

Bhaskar, R. 2008. A Realist Theory of Science. $3^{\text {rd }}$ edition. London: Verso.

Bingley, P., M. Corak and N. Westergård-Nielsen. 2011. The Intergenerational Transmission of Employers in Canada and Denmark. IZA Discussion Paper No. 5593. Bonn: Institute for the Study of Labor.

Blaug, M. 1976. "The Empirical Status of Human Capital Theory: A Slightly Jaundiced Survey." Journal of Economic Literature, 14 (3): 827- 855.

Boliver, V. 2011. "Expansion, Differentiation, and the Persistence of Social Class Inequalities in British Higher Education." Higher Education, 61: 229-242.

Boliver, V. 2013. "How Fair is Access to More Prestigious UK Universities?" British Journal of Sociology, 64 (2): 344-364.

Borgen, N. (2015). "College Quality and the Positive Selection Hypothesis: The 'Second Filter' on Family Background in High-Paid Jobs." Research in Social Stratification and Mobility, 39: 32-47.

Bourdieu, P. 1984. Distinction: A Social Critique of the Judgment of Taste. London: Routledge and Kegan Paul.

Bourdieu, P. 1988. Homo Academicus. Stanford, CA: Stanford University Press.

Bourdieu, P. 1993. The Field of Cultural Production. New York: Columbia University Press.

Bourdieu, P., and J.-P. Passeron. 1977/1990. Reproduction in Education, Society and Culture. London: Sage.

Bowles, S., and H. Gintis1976. Schooling in Capitalist America: Educational Reform and the Contradictions of Economic Life. New York: Basic Books.

Britton, J., L. Dearden, N. Shephard, and A. Vignoles. 2016. How English Domiciled Graduate Earnings Vary with Gender, Institution Attended, Subject and Socioeconomic Background. London: Nuffield Foundation.

Brown, P., H. Lauder, and D. Ashton. 2012. The Global Auction: The Broken Promises of Education, Jobs, and Incomes. Oxford: Oxford University Press.

Carabelli, A., and M. Cedrini. 2014. "Chapter 18 of The General Theory 'Further Analysed': Economics as a Way of Thinking." Cambridge Journal of Economics, 38: 23-47.

Chapman, B., T. Higgins and J. Stiglitz, eds. 2014. Income Contingent Loans: Theory, Practice and Prospects. Basingstoke and New York, NY: Palgrave Macmillan.

Collins, R. (1979). The Credential Society: An Historical Sociology of Education and 
Stratification. Oxford: Oxford University Press.

Corak, M. (2012). Inequality from Generation to Generation: The United States in Comparison. Graduate School of Public and International Affairs, University of Ottawa, Ottawa Canada.

Delaney, L., C. Harmon, and C. Redmond. 2011. "Parental Education, Grade Attainment and Earnings Expectations Among University Students. Economics of Education Review, 30 (6): 1136-1162.

Denison, E. 1962. The Sources of Economic Growth in the United States and the Alternative Before Us. New York: Committee for Economic Development.

Dow, S. 1990. "Beyond Dualism." Cambridge Journal of Economics, 14: 143-157.

Dow, S. 2012. "Different Approaches to the Financial Crisis." Economic Thought, 1: 80-93. Fligstein, N., and D. McAdam. 2015. A Theory of Fields. Oxford: Oxford University Press. Friedman, M. 1953. "The Methodology of Positive Economics." In M. Friedman, Essays in Positive Economics, 3-43. Chicago: University of Chicago Press.

Gerber, T., and S. Cheung. 2008. "Horizontal Stratification in Postsecondary Education: Forms, Explanations, and Implications.” Annual Review of Sociology, 34: 299-318.

Glomm, G., and B. Ravikumar. 1992. "Public Versus Private Investment in Human Capital: Endogenous Growth and Income Inequality." Journal of Political Economy, 100 (4), 818834.

Goodman, D. 2014. Class in Contemporary China. Cambridge: Polity.

Hallsten, M. 2014. "Inequality Across Three and Four Generations in Egalitarian Sweden: 1st and 2nd Cousin Correlations in Socio-economic Outcomes." Research in Social Stratification and Mobility, 35 (1): 19-33.

Hanley, C. 2011. "Investigating the Organizational Sources of High-Wage Earnings Growth and Rising Inequality.” Social Science Research, 40: 902-916.

Hansen, H. 2011. "Rethinking Certification Theory and the Educational Development of the United States and Germany." Research in Social Stratification and Mobility 29: 31-55

Hennessy, P. 2014. Establishment and Meritocracy. London: Haus Publishing.

Hodgson, G. 2014. "What is Capital? Economists and Sociologists Have Changed Its Meaning: Should It Be Changed Back?" Cambridge Journal of Economics, 38: 10631086.

Hoxby, C., and C. Avery. 2013. The Missing 'One-offs': The Hidden Supply of Highachieving, Low-income Students. Brookings Papers on Economic Activity, Spring.

$\mathrm{Hu}$, A., and N. Vargas. 2015. "Horizontal Stratification of Higher Education in Urban China. Higher Education. DOI 10.1007/s10734-014-9833-y.

Hussain, I., S. McNally, and S. Telhaj. 2009. University Quality and Graduate Wages in the $U K$. IZA Discussion Paper No. 4043. Bonn: Institute for the Study of Labor.

Keeley, B. 2007. Human Capital. Paris: OECD.

Kerr, C. 2001. The Gold and the Blue: A Personal Memoir of the University of California, 1949-1967. Volume 1: Academic Triumphs. Berkeley: University of California Press.

Keynes, J. M. 1921/1973. A Treatise on Probability. Reprinted in Johnson, E., and D. Moggridge, eds. The Collected Writings of John Maynard Keynes, Vol. 8. London: Macmillan, for the Royal Economic Society.

Keynes, J.M. 1933/1972. Essays in Biography. Reprinted in Johnson, E., and D. Moggridge, eds. The Collected Writings of John Maynard Keynes, Vol. 10. London: Macmillan, for the Royal Economic Society.

Keynes, J. M. 1936/1973. The General Theory of Employment, Interest and Money. Reprinted in Johnson, E., and D. Moggridge, eds. The Collected Writings of John Maynard Keynes, Vol. 7. London: Macmillan, for the Royal Economic Society.

Lawson, T. 2003. Reorienting Economics. London: Routledge. 
Lawson, T. 2012. "Mathematical Modelling and Ideology in the Economics Academy:

Competing Explanations of the Failings of the Modern Discipline?" Economic Thought 1: $3-22$.

Lemieux, T. 2006. "Postsecondary Education and Increasing Wage Inequality." AEA Papers and Proceedings. May.

Li, H., L. Meng, X. Shi, and B. Wu. 2012. "Does Attending Elite Colleges Pay in China?" Journal of Comparative Economics 40: 78-88.

Lukes, S. 1973. Individualism. Oxford: Basil Blackwell.

Marginson, S. 2016a. The Dream is Over: The Crisis of Clark Kerr's California Idea of Higher Education. Berkeley: University of California Press and the Center for Studies in Higher Education, University of California.

Marginson, 2016b. "High Participation Systems of Higher Education". The Journal of Higher Education, 87 (2): 243-270.

Marshall, A. 1898. "Distribution and Exchange.” Economic Journal, 8 (29): 37-59.

Marshall, A. 1920/1961. Principles of Economics. Revised Edition. London: Macmillan.

Melguizo, T., and G. Wolniak. 2012. "The Earnings Benefits of Majoring in STEM Fields Among High Achieving Minority Students." Research in Higher Education, 53: 383-405.

Mincer, J. 1958. "Investment in Human Capital and Personal Income Distribution." Journal of Political Economy, 66 (4): 281-302.

Mouw, T., and A. Kalleberg. 2010. "Occupations and the Structure of Wage Inequality in the United States, 1980s to 2000s.” American Sociological Review, 75 (3): 402-431.

Organisation for Economic Cooperation and Development, OECD. 2014a. Education at a Glance 2014. Paris: OECD.

Organisation for Economic Cooperation and Development, OECD. 2014b. United States: Tackling High Inequalities, Creating Opportunities for All. Paris: OECD.

Piketty, T. 2014. Capital in the Twenty-first Century. Cambridge, MA: Belknap Harvard University Press.

Psacharopoulos, G. 1994. "Returns to Investment in Education: A Global Update." World Development, 22 (9): 1325-1343.

Rivera, L. 2015. Pedigree: How Elite Students Get Elite Jobs. Princeton, NJ: Princeton University Press.

Robst, J. 2007. "Education and Job Match: The Relatedness of College Major and Work." Economics of Education Review, 26: 397-407.

Roksa, J. 2005. "Double Disadvantage or Blessing in Disguise? Understanding the Relationship between College Major and Employment Sector." Sociology of Education, 78 (3): 207-232.

Roksa, J., and T. Levey. 2010. "What Can You Do With That Degree? College Major and Occupational Status of College Graduates over Time.” Social Forces, 89 (2): 389-416.

Romer, P. 1990. “Endogenous Technological Change.” Journal of Political Economy, 98: 71102.

Saez, E. 2013. "Striking it Richer. The Evolution of Top Incomes in the United States." Berkeley: University of California, Berkeley, Department of Economics. http://eml.berkeley.edu// saez/saez-UStopincomes-2012.pdf

Sayer, A. 2000. Realism and Social Science. London: Sage.

Schneider, B., and D. Stevenson. 1999. The Ambitious Generation: America's Teenagers Motivated but Directionless. New Haven, CT: Yale University Press.

Schultz, T. 1959. "Investment in Man: An Economist's view." Social Service Review, 33 (2): 109-117.

Schultz, T. 1960. “Capital Formation by Education.” Journal of Political Economy, 68 (6): 571-583. 
Schultz, T. 1961. "Investment in Human Capital." American Economic Review, 51 (1): 1-17. Soares, J. 2007. The Power of Privilege: Yale and America's Elite Colleges. Stanford: Stanford University Press.

Social Mobility Commission, United Kingdom 2016. Socio-economic Diversity in Life Sciences and Investment Banking. London: Social Mobility Commission.

Spring, J. 2015. Economization of Education: Human Capital, Global Corporations, Skillsbased Schooling. New York: Routledge.

Stiglitz, J. 2013. The Price of Inequality. Penguin: London.

Taylor, C. 2007. A Secular Age. Cambridge, MA: Harvard University Press.

Teichler, U. 2009. Higher Education and the World of Work: Conceptual Frameworks, Comparative Perspectives, Empirical Findings. Rotterdam: Sense Publishers.

Tholen, G., P. Brown, S. Power, and A. Allouch. 2013. "The Role of Networks and Connections in Educational Elites' Labour Market Entrance." Research in Social Stratification and Mobility, 34: 142-154.

Thomsen, P., M. Munk, M. Eiberg-Madsen and G. Hansen. 2013. "The Educational Strategies of Danish University Students from Professional and Working Class Backgrounds." Comparative Education Review, 57 (3): 457-480.

Triventi, M. 2013. "The Role of Higher Education Stratification in the Reproduction of Social Inequality in the Labor Market." Research in Social Stratification and Mobility, 32: 45-63.

Trow, M. 1973. Problems in the Transition from Elite to Mass Higher Education. Berkeley, CA: Carnegie Commission on Higher Education.

United Nations Educational, Scientific and Cultural Organisation, UNESCO. 1968. Readings in the Economics of Education. Paris: UNESCO.

van de Werfhorst, H. 2002. "Fields of Study, Acquired Skills and the Wage Benefit from a Matching Job.” Acta Sociologica, 45: 286-303

Wolniak, G., T. Seifert, E. Reed, and E. Pascarella. 2008. "College Majors and Social Mobility." Research in Social Stratification and Mobility, 26: 123-139.

Zhao, W. 2012. "Economic Inequality, Status Perceptions, and Subjective Well-being in China's Transitional Economy." Research in Social Stratification and Mobility, 30: 433450 . 
